\title{
Surgical Positioning: Evidence for Nursing Care ${ }^{1}$
}

\author{
Camila Mendonça de Moraes Lopes²
}

Cristina Maria Galvão ${ }^{3}$

\begin{abstract}
The goal of surgical positioning is to promote access to the surgical site. It should be carried out correctly to ensure patient safety and prevent complications. This integrative literature review aimed to search for and evaluate available evidences in literature about nursing care related to surgical positioning of adult patients in the intraoperative period. Pubmed, Cinahl and Lilacs databases were used for the selection of the articles. The sample consisted of 20 articles. The synthesis of the available evidence showed that included studies focused on three main topics: risk factors for developing complications, complications due to surgical positioning and nursing care related to surgical positioning. Among the gaps in the research theme, the need to conduct studies on effective devices for each type of surgical position is highlighted.
\end{abstract}

Descriptors: Perioperative Nursing; Nursing Care; Research.

\footnotetext{
${ }^{1}$ Paper extracted from Master's Thesis "Posicionamento Cirúrgico: evidências para o cuidado de enfermagem", presented to Escola de Enfermagem de Ribeirão Preto, Universidade de São Paulo, SP, Brazil.

Escola de Enfermagem de Ribeirão Preto, Universidade de São Paulo, WHO Collaborating Centre for Nursing Research Development, $\mathrm{SP}$, Brazil:

2 RN, M.Sc. in Nursing. E-mail: camila.mm@usp.br.

${ }^{3}$ RN, Associate Professor. E-mail: crisgalv@eerp.usp.br.
}

Corresponding Author:

Cristina Maria Galvão

Universidade de São Paulo. Escola de Enfermagem de Ribeirão Preto

Av. Bandeirantes, 3900

Monte Alegre

CEP:14040-902 Ribeirão Preto, SP, Brasil

E-mail: crisgalv@eerp.usp.br 


\section{Posicionamento cirúrgico: evidências para o cuidado de enfermagem}

O posicionamento cirúrgico tem como principal finalidade promover o acesso ao sítio cirúrgico e deve ser realizado de forma correta para garantir a segurança do paciente e prevenir complicações. O presente estudo teve como objetivo buscar e avaliar as evidências disponíveis na literatura sobre os cuidados de enfermagem, relacionados ao posicionamento cirúrgico do paciente adulto no período intraoperatório. O método de pesquisa adotado foi a revisão integrativa da literatura. Para a seleção dos artigos, utilizaram-se as bases de dados PubMed, Cinahl e Lilacs. A amostra constitui-se de 20 artigos. Na síntese das evidências constatou-se que os artigos incluídos enfocaram três tópicos principais, a saber: os fatores de risco para o desenvolvimento de complicações; as complicações decorrentes do posicionamento cirúrgico e os cuidados de enfermagem relacionados ao posicionamento cirúrgico. Dentre as lacunas do tema investigado, destaca-se a necessidade de condução de estudos sobre dispositivos eficazes para cada tipo de posição cirúrgica.

Descritores: Enfermagem Perioperatória; Cuidados de Enfermagem; Pesquisa.

\section{Posicionamiento quirúrgico: evidencias para el cuidado de enfermería}

El posicionamiento quirúrgico tiene como principal finalidad promover el acceso al sitio quirúrgico y debe ser realizado de forma correcta para garantizar la seguridad del paciente y prevenir complicaciones. El presente estudio tuvo como objetivo buscar y evaluar las evidencias disponibles en la literatura sobre los cuidados de enfermería, relacionados al posicionamiento quirúrgico del paciente adulto en el período intraoperatorio. El método de investigación adoptado fue la revisión integradora de la literatura. Para la selección de los artículos, se utilizaron las bases de datos PubMed, Cinahl y Lilacs. La muestra se constituyó de 20 artículos. En la síntesis de las evidencias se constató que los artículos incluidos enfocaron tres tópicos principales, que son: los factores de riesgo para el desarrollo de complicaciones, las complicaciones provenientes del posicionamiento quirúrgico y los cuidados de enfermería relacionados al posicionamiento quirúrgico. Entre los vacíos del tema investigado, se destaca la necesidad de conducir estudios sobre dispositivos eficaces para cada tipo de posición quirúrgica.

Descriptores: Enfermería Perioperatoria; Atención de Enfermería; Investigación.

\section{Introduction}

Intraoperative nurses are responsible for planning and putting in practice nursing interventions that minimize or make it possible to prevent complications deriving from the anesthetic-surgical procedure, with a view to the patient's safety, comfort and individuality ${ }^{(1)}$.

The patient's surgical positioning is an important procedure in intraoperative nursing care. The main goal of this procedure is to promote optimal exposure of the surgical site and, at the same time, prevent complications deriving from surgical positioning. Therefore, teamwork and the use of specific positioning devices and equipment for each patient are essential. Nurses share the decision on how to best position the patient to facilitate activities during anesthesia and surgery with the team (surgeon, anesthetist and nursing staff). For this purpose, the patient's anatomic and physiological alterations need to be identified, associated with the type of anesthesia, procedure type and surgical time he/she will be submitted to, so that the positioning is adequate and does not cause postoperative complications ${ }^{(2)}$.

This research is motivated by the lack of Brazilian research about nursing care in surgical positioning and 
the importance of research to support decision making by perioperative nurses, who have limited access to literature due to a lack of time and difficulties to seek and analyze available evidence and apply it in clinical practice.

The theoretical framework adopted to develop this research was Evidence-Based Practice (EBP). The EBP approach integrates the best evidence from research with professionals' clinical competency and patients and family members' preferences in decision making in highquality health care ${ }^{(3)}$.

The practice of EBP in nursing encourages nurses to do research directed at clinical practice needs and/or the use of research results available in literature ${ }^{(4)}$.

\section{Purpose}

This research aimed to search for and assess evidence available in literature about nursing care related to surgical positioning of adult patients in the intraoperative period.

\section{Methodological procedure}

The adopted research method was an integrative literature review. This method includes systemized analysis and synthesis of research results on the same theme, contributes to deepen the research theme, supports decision making and, consequently, the improvement of clinical practice, based on preexisting research results ${ }^{(5-6)}$.

The following steps were followed to elaborate this integrative review: identification of theme or formulation of guiding question; sampling or literature search for studies; assessment of studies included in the review; discussion and interpretation of results and synthesis of knowledge evidenced in analyzed articles or presentation of integrative review results ${ }^{(5,7)}$.

The guiding question to elaborate the integrative review was: what is the nursing care related to surgical positioning of adult patients in the intra-operative period?

For the article search, the internet was used to access the following databases: PubMed (digital biomedical and health science files from the US National Institutes of Health), CINAHL (Cumulative Index to Nursing and Allied Health Literature) and LILACS (Latin American and Caribbean Health Science Literature).

Keywords related to the theme were selected and it was checked in the databases whether these were controlled descriptors according to each specific database indexation. Table 1 displays the descriptors used to conduct the integrative review.

Table 1 - Controlled and uncontrolled descriptors according to selected databases

\begin{tabular}{|c|c|c|}
\hline Database & Controlled descriptors & Uncontrolled descriptors \\
\hline \multirow[t]{9}{*}{ PubMed } & Intraoperative period & Intraoperative positioning \\
\hline & Intraoperative care & Patient positioning \\
\hline & Intraoperative & Surgical positioning \\
\hline & complications & \\
\hline & Intraoperative & Surgical patient \\
\hline & procedures & positioning \\
\hline & Perioperative nursing & Intraoperative nursing \\
\hline & Operating room nursing & \\
\hline & Nursing care & \\
\hline \multirow[t]{11}{*}{ LILACS } & Período intraoperatório & Posicionamento \\
\hline & Complicações & Postura \\
\hline & intraoperatórias & \\
\hline & Cuidados & \\
\hline & intraoperatórios & \\
\hline & Enfermagem & \\
\hline & perioperatória & \\
\hline & Enfermagem de centro & \\
\hline & cirúrgico & \\
\hline & Cuidados de & \\
\hline & enfermagem & \\
\hline \multirow[t]{8}{*}{ CINAHL } & Intraoperative care & Perioperative period \\
\hline & Intraoperative period & \\
\hline & Intraoperative & \\
\hline & complications & \\
\hline & Perioperative positioning & \\
\hline & injury & \\
\hline & Perioperative care & \\
\hline & Perioperative nursing & \\
\hline
\end{tabular}

With a view to a broad article search, all possible combinations among the descriptors were searched in each database. The following inclusion criteria were adopted: article on nursing care to adult patients in surgical positioning in the intraoperative period; published in English, Spanish and Portuguese between July 1998 and July 2008 and articles without distinguishing the adopted research design.

The articles were selected by their title and abstract, in line with the study goal and in compliance with the inclusion criteria. Six hundred references were preselected in PubMed, 140 in LILACS and 754 in CINAHL, totaling 1494 articles, which resulted in a sample of 20 articles that were analyzed in full. To extract the data, a previously published and validated data collection instrument was used ${ }^{(8)}$. To analyze the evidence level and research design of the studies included in the 
review, the concepts proposed by nursing researchers were used ${ }^{(3,9)}$.

The articles were analyzed and summarized descriptively, allowing readers to assess the quality of evidence (evidence level) available in literature on the research theme, support decision making in daily intraoperative nursing and identifying knowledge gaps with a view to future research.

\section{Results}

Twenty articles were included in the review, nineteen of which were published in English and one in Portuguese; among the publications' countries of origin, the United States predominated with thirteen articles.
Papers were published in a range of journals, particularly the AORN Journal (four articles).

With regard to the evidence level, only one study showed a strong evidence level (level II) with an experimental design, i.e. controlled randomized clinical trials; one study was considered of moderate evidence level (level III) with a quasi-experimental design, i.e. assessments (process analysis), and eight studies presented weak evidence (levels VI and VII), three with a non-experimental design, two descriptive, crosssectional studies and three experience reports. In the same sense, the other ten studies (narrative literature reviews) are not classified according to the adopted hierarchical system. Tables 2, 3, 4 and 5 show the synthesis of the analyzed articles.

Table 2 - Synthesis of research with experimental and quasi-experimental research design

\begin{tabular}{|c|c|c|c|}
\hline Research & Purpose & Result & Conclusion \\
\hline $\begin{array}{l}\text { Feuchtinger et } \\
\text { al. }^{(10)} \\
\text { Controlled } \\
\text { randomized clinical } \\
\text { trial }(n=300)\end{array}$ & $\begin{array}{l}\text { Assess the efficacy of using a } 4 \mathrm{~cm} \\
\text { thermoactive viscoelastic foam pad to } \\
\text { reduce surgical positioning injuries. }\end{array}$ & $\begin{array}{l}\text { No significant statistical difference } \\
\text { was found between the trial (tested } \\
\text { device) and control (usual care) } \\
\text { groups. }\end{array}$ & $\begin{array}{l}\text { Further research is needed to identify } \\
\text { effective devices to prevent surgical } \\
\text { positioning injuries. }\end{array}$ \\
\hline $\begin{array}{l}\text { Power }^{(11)} \\
\text { Assessment } \\
\text { (process analysis) }\end{array}$ & $\begin{array}{l}\text { Assess postoperative pain } \\
\text { experience related to type of surgical } \\
\text { positioning in patients submitted to } \\
\text { gynecological surgeries. }\end{array}$ & $\begin{array}{l}\text { The frequency of patients' pain } \\
\text { reports increased with age and } \\
\text { duration of surgery. No difference } \\
\text { was found in pain incidence or } \\
\text { severity with regard to type of } \\
\text { positioning. }\end{array}$ & $\begin{array}{l}\text { The author recommends that perioperative } \\
\text { nurses should document the adopted } \\
\text { interventions and relate them with clinical } \\
\text { findings, so as to rethink practice and } \\
\text { attempt to improve nursing care. }\end{array}$ \\
\hline
\end{tabular}

Table 3 - Synthesis of research with non-experimental research design

\begin{tabular}{|c|c|c|c|}
\hline Research & Purpose & Result & Conclusion \\
\hline $\begin{array}{l}\text { Roeder et al. }{ }^{(12)} \\
\text { Descriptive cross- } \\
\text { sectional research }\end{array}$ & $\begin{array}{l}\text { Assess capillary pressure } \\
\text { supported in the heel and } \\
\text { calf region in individuals in } \\
\text { lithotomy position. }\end{array}$ & $\begin{array}{l}\text { Pressure increases with increased height } \\
\text { of calf support in variation of lithotomy } \\
\text { position and the larger the support surface, } \\
\text { the lower the capillary pressure supported. }\end{array}$ & $\begin{array}{l}\text { The authors recommend the use of } \\
\text { the lowest heel position; placement } \\
\text { of support under the greatest contact } \\
\text { area and maintaining the patient in } \\
\text { the lithotomy position for the shortest } \\
\text { possible time. }\end{array}$ \\
\hline $\begin{array}{l}\text { Matos, Piccoli }{ }^{(13)} \\
\text { Descriptive cross- } \\
\text { sectional research }\end{array}$ & $\begin{array}{l}\text { Verify the frequency of the risk } \\
\text { for perioperative positioning } \\
\text { injury nursing diagnosis, } \\
\text { defining characteristics and } \\
\text { related factors. }\end{array}$ & $\begin{array}{l}\text { The diagnosis was identified in } 100 \% \text { of } \\
\text { the sample. The defining characteristics } \\
\text { and identified factors were loss of habitual } \\
\text { protective barrier after anesthesia and } \\
\text { commitment of tissue perfusion after cold } \\
\text { in surgery room with frequencies of more } \\
\text { than } 50 \% \text {. }\end{array}$ & $\begin{array}{l}\text { Nurses should plan actions based on } \\
\text { each patient's specific characteristics, } \\
\text { the patient's surgical positioning is } \\
\text { what determines a safe and efficient } \\
\text { procedure. }\end{array}$ \\
\hline $\begin{array}{l}\text { Stevens et al. }{ }^{(14)} \\
\text { Retrospective } \\
\text { correlation research }\end{array}$ & $\begin{array}{l}\text { Analyze the injuries of patients } \\
\text { submitted to urological surgical } \\
\text { procedures, correlated with } \\
\text { predisposing factors. }\end{array}$ & $\begin{array}{l}\text { Surgical positioning and prolonged surgery } \\
\text { time were significantly associated with the } \\
\text { development of skin injuries. The risk of } \\
\text { developing injuries is greater in patients } \\
\text { placed in the lateral position, which is } \\
\text { chosen in urological surgeries. }\end{array}$ & $\begin{array}{l}\text { The skin injuries developed by patients } \\
\text { submitted to urological surgeries derived } \\
\text { from surgical positioning and this } \\
\text { procedures demands care and attention } \\
\text { by the intraoperative team. }\end{array}$ \\
\hline
\end{tabular}


Table 4 - Synthesis of expert opinion and experience report research

\begin{tabular}{|c|c|c|}
\hline Research & Purpose & Synthesis \\
\hline $\begin{array}{l}\text { AORN }{ }^{(15)} \\
\text { Expert opinion }\end{array}$ & $\begin{array}{l}\text { Offer perioperative nurses } \\
\text { best-practice guidelines for } \\
\text { patient positioning. }\end{array}$ & $\begin{array}{l}\text { The Association constructed practical recommendations in six standards, which are: I. } \\
\text { Preoperative assessment of patient's special surgical positioning needs, II. Devices to support } \\
\text { positioning should be available, clean and preferably maintain normal capillary interface } \\
\text { pressure, III. The nurse should monitor the patient's body alignment and tissue integrity } \\
\text { based on physiological principles, IV. After the positioning, the nurse should assess the } \\
\text { patient again, V. Positioning documentation should follow "AORN Recommended practices } \\
\text { for documentation of perioperative nursing care", VI. Institutional standards and procedures } \\
\text { for deciding on patient positioning should be reviewed and updated every year and should be } \\
\text { followed by all participants in this activity. }\end{array}$ \\
\hline $\begin{array}{l}\text { Richardson }^{(16)} \\
\text { Expert opinion }\end{array}$ & $\begin{array}{l}\text { Describe the use of a } \\
\text { type of leg holder and its } \\
\text { benefits during surgical } \\
\text { patient positioning. }\end{array}$ & $\begin{array}{l}\text { The author describes the use of a new type of leg holder to place the patient in the lithotomic } \\
\text { position, which is called "Direct Placement Leg Holders" (DPLHs). This device is easy to } \\
\text { move, fix and position, besides reducing heel and calf pressure. It facilitates routine and } \\
\text { promotes patient safety. Nurses are responsible for providing the best equipment and } \\
\text { guaranteeing its correct use so as to provide better patient care. }\end{array}$ \\
\hline $\begin{array}{l}\text { Carris, Franczek }{ }^{(17)} \\
\text { Experience report }\end{array}$ & $\begin{array}{l}\text { Describe a surgical } \\
\text { positioning device for } \\
\text { patients submitted to } \\
\text { endoscopic urological } \\
\text { procedures. }\end{array}$ & $\begin{array}{l}\text { The authors describe difficulties to place obese patients in the lithotomic position after } \\
\text { induced anesthesia. They report on the use of a } 91.44 \times 60.96 \mathrm{~cm} \text { smooth plastic device that } \\
\text { is cheap and normally used for snow sliding, covered by a surgical drape and placed under } \\
\text { the patient. Soon after anesthetic induction, this device helps to slide the patient to the lower } \\
\text { part of the table, a simple procedure that facilitated patient positioning, avoiding injuries in the } \\
\text { patient and team, and which can be used at any other surgical center. }\end{array}$ \\
\hline $\begin{array}{l}\text { Murphy }{ }^{(18)} \\
\text { Experience report }\end{array}$ & $\begin{array}{l}\text { Report on three cases with } \\
\text { legal decisions involving } \\
\text { intraoperative injuries } \\
\text { deriving from surgical } \\
\text { positioning. }\end{array}$ & $\begin{array}{l}\text { In the three cases of surgical positioning injuries, no negligence by the perioperative } \\
\text { nursing team was evidenced. It serves as an alert to nurses though, so as to take care while } \\
\text { transporting, transferring and positioning the patient on the surgery table, using due protection } \\
\text { and padding, highlighting the importance of documentation so as to provide legal support for } \\
\text { the delivered care. }\end{array}$ \\
\hline $\begin{array}{l}\text { Schulman et al. }{ }^{(19)} \\
\text { Experience report }\end{array}$ & $\begin{array}{l}\text { Describe an intraoperative } \\
\text { positioning technique for } \\
\text { burned patients. }\end{array}$ & $\begin{array}{l}\text { The technique is used to permit free access to structures that need to be debrided in burned } \\
\text { patients. Correct positioning favors a shorter surgery time and, consequently, decreases the } \\
\text { number of interventions and reduces the risk of complications. }\end{array}$ \\
\hline
\end{tabular}

Table 5 - Synthesis of narrative literature review research

\begin{tabular}{lll}
\hline Research & Purpose & Synthesis
\end{tabular}

Hoshowsky(20) Discuss the main points during surgical positioning of orthopedic surgery patients.

Taylor, Campbell ${ }^{(21)}$

Review the prevention of surgical procedure errors, surgical positioning and care with pressure areas.

Keller $^{(22)}$

Describe the risk factors that can be intensified in obese surgical patients.

Heizenroth $^{(23)}$
Describe the causes of nerve injuries in surgical patients, with a view to guiding practice and planning care.
The goals of surgical positioning are: promote the best exposure of the surgical site, access to ventilation and monitoring, maintenance of physiological functions, patient comfort, safety and privacy. Nursing interventions for orthopedic surgery patients depend on the type of position and previous assessment is needed to know each patient's particularities.

The following is recommended for patient positioning: check if equipment and operation table are clean and safe, move patient carefully, place and fix him/her in the desired position, take care with pressure points, as skin injuries can be caused by long stay on the table, based positioning and/or inadequate moving, associated with factors like age, weight, nutritional state and temperature control.

Transportation and surgical positioning of obese patients demand adequate planning to avoid injuries in operating room staff and patients. Surgical devices, equipment and instruments adequate to obese patients' size should be provided in advance. In obese patients, the author recommends the prohibition of the Trendelemburg, supine and prone positions.

Causes of injuries can be related to imposed forces due to surgical positioning for a long period; tissue hyperextension or compression, which can leave nerves without oxygen and cause damage, which can be temporary or permanent. Correct patient positioning, padding and monitoring in the intraoperative period help to prevent these complications 
Table 5 - Continuation

\begin{tabular}{|c|c|c|}
\hline Research & Purpose & Synthesis \\
\hline Troia ${ }^{(24)}$ & $\begin{array}{l}\text { Analyze risk factors and care } \\
\text { needed for obese surgical } \\
\text { patients. }\end{array}$ & $\begin{array}{l}\text { Planning and putting in practice effective actions can prevent complications. Adequate } \\
\text { care for obese patients demands the availability of adequate positioning, transfer and } \\
\text { mobilization equipment for the patient's body and some positions, such as the lithotomic } \\
\text { position, should be avoided. }\end{array}$ \\
\hline Wilde ${ }^{(25)}$ & $\begin{array}{l}\text { Describe the Compartment } \\
\text { Syndrome (CS). }\end{array}$ & $\begin{array}{l}\text { CS is a potentially fatal disease that occurs when perfusion pressure drops below tissue } \\
\text { perfusion in one compartment, developing ischemia on the site. Correct and safe surgical } \\
\text { positioning with the use of adequate devices and its maintenance during the intraoperative } \\
\text { period is a fundamental conduct for all people involved in patient care. }\end{array}$ \\
\hline Dybec $^{(26)}$ & $\begin{array}{l}\text { Appoint the main considerations } \\
\text { about surgical positioning of } \\
\text { obese patients. }\end{array}$ & $\begin{array}{l}\text { Some surgical positions increase the potential risk of complications in obese patients, } \\
\text { such as the supine and prone position; while others can be beneficial, such as the lateral } \\
\text { position. Equipment needed to support positioning should be assessed and selected } \\
\text { before the patient arrives at the surgery room. An adequate number of staff should be } \\
\text { present for transfer to the surgery table. }\end{array}$ \\
\hline Millsaps ${ }^{(27)}$ & $\begin{array}{l}\text { Review the main points during } \\
\text { surgical positioning. }\end{array}$ & $\begin{array}{l}\text { The development of adequate positioning techniques, the use of support equipment and } \\
\text { padding devices contribute to patient safety. Care planning, considering surgery time, } \\
\text { surgery type and anesthesia, besides the identification of risk factors for each patient, will } \\
\text { determine what device is adequate. }\end{array}$ \\
\hline O'Connell(28) & $\begin{array}{l}\text { Describe the types of surgical } \\
\text { positions and nursing care in } \\
\text { patient positioning. }\end{array}$ & $\begin{array}{l}\text { The main positions mentioned are supine, lithotomic, lateral and prone. Potential } \\
\text { complications deriving from surgical positioning increase in anesthetized patients. Care } \\
\text { should be taken with plexi and nerve sites, impeding the occurrence of nerve injuries; } \\
\text { assess prominent bones in contact with the surgery table and guarantee that capillary } \\
\text { pressure remains } \leq 32 \mathrm{mmHg} \text {; respect body alignment and use specific devices to support } \\
\text { positioning for each type of position and patient needs. }\end{array}$ \\
\hline Murphy ${ }^{(29)}$ & $\begin{array}{l}\text { Identify court cases related to } \\
\text { operative injuries. }\end{array}$ & $\begin{array}{l}\text { A literature review was carried out in the LexisNexis database between February } 2002 \\
\text { and February 2004, using the keywords: "operating room and nurse", "negligence or } \\
\text { malpractice". Seventy-eight cases were found in three legal instances, four of which were } \\
\text { related to pressure ulcer deriving from surgical positioning. Positioning should be planned } \\
\text { in advance and involve the entire team. }\end{array}$ \\
\hline
\end{tabular}

\section{Discussion}

The synthesis of research data from the review studies revealed that these focused on three main themes, which were: risk factors for the development of complications, complications deriving from surgical positioning and nursing care related to the patient's surgical positioning.

Preoperative assessment of each surgery patient's risk factors and their consideration in the elaboration of the care plan can contribute so as not to develop complications in the intraoperative period(20-28). All identified risk factors should be documented, as well as orientations patients received(29).

The main risk factors mentioned were: general anesthesia - situation in which the body loses physiological protection for compensation mechanisms and is susceptible to muscle and/or nerve injuries and pain. Using drugs like muscle relaxants and pain medication can mask and delay the diagnosis of intraoperative injuries ${ }^{(20-28)}$;

age - elderly or very young patients can have a more sensitive skin and greater probability to develop skin injuries ${ }^{(20-21,25,27-28)}$;

weight - assess the body mass index, as obesity and overweight can lead to a higher potential of complications due to positioning and low weight causes increased exposure of the patient's bone prominences, which are regions more susceptible to the appearance of skin injuries ${ }^{(20-22,24-28)}$;

immobility or mobilization problems - make surgical positioning more difficult and can favor the formation of blood clots and pressure points ${ }^{(20,23--25,27-28)}$;

body temperature control problems - as a result of hypothermia, body structures depend on more oxygen and, without the necessary inflow, this can favor the formation of necrosis or tissue death(20-21,26,28); 
preexisting health conditions - diabetes mellitus, cancer, kidney failure, low preoperative hematocrit and hemoglobulin levels, vascular, heart and respiratory diseases and conditions affecting the immune system can favor the development of complications(20-22, 24-28); prolonged surgery time - surgeries longer than two hours can affect the oxygenation of compressed tissues and favor the occurrence of pressure ulcers(20-28).

All studies assessed(10-29) appointed that the patient's surgical positioning causes some negative impact on body systems and can entail several complications, such as: musculoskeletal pain, joint dislocation, peripheral nerve damage, skin injuries, cardiovascular and pulmonary problems and even compartment syndrome.

The following stand out among nursing care recommendations in the analyzed articles: respect body alignment; take actions for pressure areas; reduce friction, shear and pressure; check bone prominences; select and make available positioning devices according to each patient's needs and relate them with the surgery type and time; move, transport and position the patient with an adequate number of staff and using adequate equipment to avoid occupational and patient injuries; document all positioning procedures(10,20-22,24,26-28).

The main surgical position recommendations are: supine - use pillows or supports for the head and below the knees, place arms at a maximum angle of $90^{\circ}$ with the body, keep legs uncrossed, pay attention with hyperextension of the feet;

prone - protect face, eyes and chin, favor access to tubes and monitoring lines, maintain neck alignment, place roll cushion from the collar bone to the iliac crest and under the legs and feet, leave genitals free, protect feet against hyperflexion;

lateral - maintain spinal alignment, observe ears, place a support under the head, armpit region and between the legs, keep leg in contact with the table flexed in the hip region and the superior leg stretched;

lithotomy - maintain arms in arm holders at a maximum angle of $90^{\circ}$, pad hip, buttocks and body sides, use the lowest leg elevation for the shortest possible time and minimize the hip abduction degree.

\section{Conclusion}

The conclusion of this integrative literature review evidences the importance of nursing actions in surgical positioning, including the prevention of complications deriving from this procedure, the assessment of each patient's needs and the availability of adequate equipment and devices. Nurses should become consumers of research results and/or conduct studies in response to daily problems, and should also seek strategies to put available evidence in clinical practice. In the authors opinion, this will imply the consolidation of EvidenceBased Practice.

\section{References}

1. Galvão CM. A prática baseada em evidências: uma contribuição para a melhoria da assistência de enfermagem perioperatória. [livre-docência]. Ribeirão Preto (SP): Escola de Enfermagem de Ribeirão Preto da Universidade de São Paulo; 2002. 114 p.

2. St-Arnaud $D$, Paquin M. Safe positioning for neurosurgical patients. AORN J. 2008; 87(6):1156-72.

3. Melnyk BM, Fineout-Overholt E. Making the case for evidencebased practice. In: Melnyk BM, Fineout-Overholt E. Evidencebased practice in nursing $\&$ healthcare: a guide to best practice. Philadelphia: Lippincott Williams \& Wilkins; 2005. p. 3-24.

4. Galvão CM, Sawada NO, Rossi LA. A prática baseada em evidências: considerações teóricas para sua implementação na enfermagem perioperatória. Rev Latino-am Enfermagem 2002; 10(5):690-5.

5. Mendes KDS, Silveira RCCP, Galvão CM. Revisão integrativa: método de pesquisa para a incorporação de evidências na saúde e na enfermagem. Texto Contexto Enferm. 2008; 17(4): 758-64.

6. Mendes KDS, Galvão CM. Liver transplantation: evidence for nursing care. Rev Latino-am Enfermagem 2008; 16(5):915-22.

7. Whittemore $\mathrm{R}$, Knafl $\mathrm{K}$. The integrative review: updated methodology. J Adv Nurs. 2005; 52(5):546-53.

8. Ursi ES, Galvão CM. Prevenção de lesões de pele no período perioperatório: revisão integrativa da literatura. Rev Latino-am Enfermagem 2006; 14(1):124-31.

9. Polit DF, Beck CT, Hungler BP. Fundamentos de pesquisa em enfermagem: métodos, avaliação e utilização. Porto Alegre (RS) ArtMed; 2004. 487 p.

10. Feuchtinge J, Bie R, Dassen T, Halfens R. A 4-cm thermoactive viscoelastic foam pad on the operating table to prevent pressure ulcer during cardiac surgery. J Clin Nurs. 2006; 15(2): 162-7.

11. Power $\mathrm{H}$. Patient positioning outcomes for women undergoing gynaecological surgeries. Can Oper Room Nurs J. 2002; 20(3):7$10,27-30$.

12. Roeder RA, Geddes LA, Corson N, Pell C, Otlewsk M, Kemeny A. Heel and calf capillary-support pressure in lithotomy positions. AORN J. 2005; 81(4):821-5.

13. Matos FGOA, Piccoli M. Diagnóstico de enfermagem risco para lesão perioperatória por posicionamento identificado no período transoperatório. Ciência, Cuidado e Saúde 2004; 3(2): 195-201.

14. Stevens J, Nichelson E, Linehan M, Thompson N, Liewehr D, Venzon, et al. Risk factors for skin breakdown after renal and adrenal surgery. Urology 2004; 64 (2):246-9.

15. Association of periOperative Registered Nurses. Recommended 
practices for positioning the patient in the perioperative practice setting. AORN J. 2001; 73(1):231-8.

16. Richardson $\mathrm{C}$. Use of leg positioning holders. $\mathrm{Br} \mathrm{J}$ Perioper Nurs. 2004; 14(3):127-30.

17. Carris J, Franczek T. Patient positioning: snow fun in the OR. Today Surg Nurse 1999; 21(3):47-8.

18. Murphy EK. Negligence cases concerning positioning injuries. AORN J. 2004; 80(2):311-4.

19. Schulman CI, Namias BJ, Rosales O, Pizano LR, Ward CG, Namias N. A portable, universal patient positioning and holding system for use in the burn patient 'The Burnwalter'. Burns 2005; 31(5):647-9.

20. Hoshowsky VM. Surgical positioning. Orthop Nurs. 1998; 17(5):55-65.

21. Taylor M, Campbell C. Patient care in the operating department (1). Br J Theatre Nurs. 1999; 9(6):272-5.
22. Keller $\mathrm{C}$. The obese patient as a surgical risk. Semin Perioper Nurs. 1999; 8(3):109-17.

23. Heizenroth P. Surgery: it's got some nerve! Hosp Nurs. 2001; 31(10):32hn1-4.

24. Troia C. Promoting positive outcomes in obese patients. Plast Surg Nurs. 2002; 22(1):10-7, 28.

25. Wilde $\mathrm{S}$. Compartment syndrome. The silent danger related to patient positioning and surgery. $\mathrm{Br}$ J Perioper Nurs. 2004; 14(12):546-50, 552-4.

26. Dybec RB. Intraoperative positioning and care of the obese patient. Plast Surg Nurs. 2004; 24(3):118-22.

27. Millsaps CC. Pay attention to patient positioning! RN 2006; 69(1):59-63.

28. O'Connell MP. Position impact on the patient positioning. Nurs Clin North Am. 2006; 4(12):173-92.

29. Murphy EK. Protecting patients from potential injuries. AORN J. $2004 ; 79(5): 1013-6$. 